\title{
OLD KNOWLEDGE INTO NEW PATENT LAW: THE IMPACT OF UNITED STATES PATENT LAW ON LESS-DEVELOPED COUNTRIES
}

\author{
Insoon Song*
}

\section{INTRODUCTION}

In today's highly technological world, biotechnology is one of the most innovative and intensive industries. ${ }^{1}$ Biotechnology is defined as techniques ${ }^{2}$ that use living organisms or parts of organisms to make or modify products, to improve plants or animals, or to develop microorganisms for specific uses. ${ }^{3}$ Biotechnology may also be defined as "the engineering and biology of the interaction between man and machines." the genetically-based characteristics in microorganisms, plants, and animals to create drugs and to develop drug therapies. ${ }^{5}$ These drugs or drug therapies may prevent, cure, or alleviate diseases and their symptoms. ${ }^{6}$ Also, biotechnology has been used to develop agricultural products or environmental solutions for environmental disasters. ${ }^{7}$ Genetically engineered crops or fruits are products of biotechnology. ${ }^{8}$ Biotechnology has increased production or quality of livestock

* J.D. Candidate, 2006, Indiana University School of Law - Indianapolis (expected); Master of Science, Molecular Biology, Department of Life Science and Biotechnology, Korea University, Seoul, Korea, 1998; Bachelor of Science, Genetic Engineering, Korea University, Seoul, Korea, 1996. The author would like to thank her parents, husband and other family members for their support and understanding throughout law school.

1. Akim F. Czmus, M.D., Comment, Biotechnology Protection in Japan, the European Community, and the United States, 8 TEMP. INT'L \& CoMP. L.J. 435, 435 (1994).

2. The techniques include "selecting natural strains of organisms that carry desirable traits; making hybrids by fusing cells from different parental sources; using chemicals and radiation to create mutant strains; or genetically engineering plants, animals, and microorganisms to produce specific phenotypic characteristics." JONATHAN CURCI STAFFLER, Graduate INSTTTUTE OF INTERNATIONAL STUDIES (IUHEI), GENEVA, TOWARDS A RECONCILIATION BETWEEN THE CONVENTION ON BIOLOGICAL DIVERSITY AND TRIPS AGREEMENT 5, http://www.botanischergarten.ch/Patents/Staffler-CBD-TRIPS.doc (n.d.) (last visited Oct. 28, 2005).

3. Graham Dutfield, Intellectual Property Rights aNd The Life Science INDUSTRIES: A TWENTIETH CENTURY HISTORY 135 (2003).

4. Czmus, supra note 1 , at 435 .

5. Id. at 435-36.

6. Id. at 436 .

7. Id.

8. See id. Genetic engineering is defined as "[s]cientific alteration of the structure of genetic material in a living organism. It involves the production and use of recombinant DNA and has been employed to create bacteria that synthesize insulin and other human proteins." THE AMERICAN HERITAGE DiCTIONARY OF THE ENGLISH LANGUAGE ( $4^{\text {th }}$ ed. 2004), available at http://www.answers.com/genetically+engineered\&r=67 (n.d.) (last visited Oct. 28, 2005). 
and a variety of crops. ${ }^{9}$ Genetically altered microorganisms that decompose oil spills and prevent further damage to the environment have also been developed. ${ }^{10}$ Generally, biotechnology aims to utilize scientific research and technology to create a better future for humankind. ${ }^{11}$

As the biotechnology industry grows, patent law has been expanded to protect patent rights to life forms and their structural and functional components. $^{12}$ The patent serves as a device for society to measure the value of an invention. ${ }^{13}$ It allows patentees to stipulate competitive prices for discoveries, and the products that later embody them. ${ }^{14}$ The importance of patent protection has been emphasized because biotechnology is a high-risk, extremely research-intensive activity and has always been crucial to enable biotechnology companies to secure large amounts of investment capital to stay in business. ${ }^{2}$ Patent portfolios are the main magnet for the investors of biotechnology companies. ${ }^{16}$ The larger the patent portfolio is, the greater the interest from investors. ${ }^{17}$ As a result, biotechnology patenting has experienced a tremendous increase in the last two decades. ${ }^{18}$

In this current situation, the United States is naturally very concerned about both the commercialization of biotechnology applications and products, as well as the development of patent law. ${ }^{19}$ This biotechnology boom in the United States has vastly increased corporate demand for unconventional forms of natural resources - that is, living materials found primarily in lessdeveloped countries. ${ }^{20}$ In particular, there is a "gene rush" as governments and companies aggressively scout less-developed countries in search of genetic material. $^{21}$ As a result of this development, we have seen debates concerning whether this "gene rush" from the United States is bio-prospecting or biopiracy. $^{22}$

This Note will explore the impact of the U.S. patent system on lessdeveloped countries. Part $\Pi$ of this Note will look at the U.S. patenting system.

9. Australian Government, Department of Foreign Affairs and Trade, Intellectual Property \& Biotechnology, at http://www.dfat.gov.au/publications/biotech/overview.html (last modified Jan. 20, 2004)[hereinafter Intellectual Property \& Biotechnology].

10. Czmus, supra note 1 , at 436 .

11. Id. See also Intellectual Property \& Biotechnology, supra note 9.

12. DUTFIELD, supra note 3, at 152.

13. Nuni Pires de Carvalho, The TRIPS Regime of Patent Right 1 (2002).

14. Id.

15. DưrFIELD, supra note 3 , at 153.

16. Id.

17. Id.

18. Id.

19. See id. at 154.

20. See Andrew Kimbrell, Replace Bio-piracy with Biodemocracy, (July 23, 1996), at http://www.ratical.org/ co-globalize/ReplaceBPwBD.html (last visited Oct. 28, 2005).

21. Id.

22. See Sudhir D. Ghatnekar \& Mandar S. Ghatnekar, Bio-prospecting or Bio-piracy? $\begin{array}{lllll}\text { INDIAN EXPRESS NEWSPAPER, } & \text { Feb. } & \text { 8, } & 1999 \text {, }\end{array}$ http://www.expressindia.com/fe/daily/19990208/fec0801.html . 
Specifically, Part II will first examine the history of patent law in the United States, looking at U.S. Constitutional provisions for the establishment of patent law. Part II will also explore patentability in the United States, focusing on two landmark U.S. patent cases: Diamond $v_{.}$Chakrabarty ${ }^{23}$ and J. E. M. AG Supply, Inc. $v$. Pioneer Hi-Bred Int'l, Inc. ${ }^{24}$ The third part of this section will focus on the topic of biotechnology patenting in the United States.

Part III of this Note will examine the impact of United States patents on less-developed countries. The first portion of Part III will discuss whether inventions patented by the United States using genetic resources or indigenous knowledge of less-developed countries represent bio-prospecting or bio-piracy. Four cases will be studied as examples on point. The second portion of Part III will illustrate the neem tree case from India and the rosy periwinkle case from Madagascar. This section will then illustrate the basmati rice case from India and Pakistan and the jasmine rice case from Thailand.

Part IV of this Note will discuss the effort to resolve disputes among developed countries, including the United States and less-developed countries, under Trade Related Intellectual Property Rights (TRIPS) obligations. Specifically, Part IV will first present the general features of TRIPS. This section will also look at the Convention on Biological Diversity (CBD) and TRIPS, Article 27.3(b). Also, it will discuss the relationship between the CBD and TRIPS, Article 27.3(b) for patents of the traditional or indigenous knowledge and plants, animals, and biological process. Finally, Part IV will present proposals from several countries to settle disputes between developed countries and less-developed countries under the TRIPS Agreement.

In conclusion, Part $\mathrm{V}$ of this Note proposes a means to settle patent disputes generated by this fast-developing area of science involving the United States and less-developed countries. Proposals from several countries to resolve disputes under TRIPS will be considered as background to this Note's suggested solution for patent disputes regarding indigenous knowledge and natural resources between the United States and the less-developed countries with case studies in Part II, specifically India, Pakistan, and Thailand.

\section{PATENTING SySTEM IN THE UNITEd STATES}

\section{A. History of Patent Law in the United States}

The term "patent" is derived from the original "Letters Patent,"25 granted after the fourteenth century in England. ${ }^{26}$ The purpose of the patent was to

23. 447 U.S. 303 (1980).

24. 534 U.S. 124 (2001).

25. Daniel Gervais, The TRIPS Agreement, Drafting History and ANalysis 117 (2003). "Letter Patent" means literally "open letters." Id. 
grant the inventor or importer of a new technology the sole right to use his invention for a sufficient period to establish his business. ${ }^{27}$ While the inventor or importer benefited from his patent right, the State gained technological progress. ${ }^{28}$ From the beginning, in order to obtain patent rights, the invention was required to be new in the Kingdom, and it was supposed to benefit the State. $^{29}$

In 1787 , at the Constitutional Convention, a measure was proposed to incorporate as one of the new federal powers the ability to secure the establishment of intellectual property law. ${ }^{30}$ That document states: "Congress shall have the Power ... to promote the Progress of Science and useful Arts, by securing for limited Times to Authors and Inventors the exclusive Right in their respective Writings and Discoveries."31 Based on this provision, the first patent act was passed in $1790 .^{32}$ The first patent act rejected the English practice of awarding patents to local importers of foreign inventions, instead it protected the "first and true inventor." 33 The second patent act was enacted in 1793. It denied foreigners the right to apply for patents and codified the first inventorship test - the novelty and nonobviousness test. ${ }^{34}$ The third patent law, the 1836 Patent Act, was enacted as the first modern patent law. ${ }^{35}$

Initially, Thomas Jefferson, the patent administrator and then-Secretary of State, personally examined the patent applications. ${ }^{36}$ When he became too busy to examine the applications, patents began to be granted simply upon registration. ${ }^{37}$ However, because of growing litigation between individuals with contesting claims and discontent with the patent administration, the process was reformed in 1836 Patent Act. ${ }^{38}$ Through this reformation, a formalized

26. Id. The development of American patent law can be traced back to ancient Greece. ARThur R. Miller \& Michael H. Davis, InTEllectual Property: PATENTS, Trademarks, AND COPYRIGHT IN A NUTSHELL 4 (2000). However, the acceptable starting point is the Statute of Monopolies, adopted in England in 1623. Id. This act addressed many basic patent issues that remain relevant today. Id.

27. GERVAIS, supra note 25 , at 117 . The early patent was emerged from monopolies, or so-called "guilds." MiLLER \& DAVIS, supra note 26, at 4. They were groups of artisans, and they controlled various sectors of markets. Id. at 4-5. These early patent monopolies were concerned with commerce, rather than with invention. Id. at 5. Foreigners who brought new technical skills into the jurisdiction were granted the privilege to practice a particular art or manufacturing process. Id.

28. GERVAIS, supra note 25 , at 117.

29. Id.

30. Czmus, supra note 1 , at 436 .

31. Id. (quoting U.S. CoNST. art. $1, \S 8, \mathrm{cl} .8$ ).

32. Czmus, supra note 1 , at 436.

33. DUTFIELD, supra note 3 , at 3.

34. Id.

35. Id.

36. Michael P. Ryan, KNOWLEDGe Diplomacy, Global Competition and THe Polttics OF INTELLLCTUAL PROPERTY 32 (1998).

37. Id.

38. Id. Until 1836, there was no general administrative body to examine the validity of patents. MILLER \& DAVIS, supra note 26, at 5. From 1836, the Patent Office has been vested with the authority to examine patent and determine requirements for patent applications. Id. 
examination system was established, and technical experts were recruited to restore the patent policy. ${ }^{39}$ This 1836 law lasted without amendment until the 1952 Patent Act, which demands that the inventor distinctly specify the claims for his invention. ${ }^{40}$ The patent specifications were required to particularly point out and distinctly claim the subject matter which the applicant regarded as his invention. ${ }^{41}$

Since the first patent act was enacted, the purpose of patent law has been to grant the owner of a patent the absolute and exclusive right to determine who will be able to use, make, or sell the patented item through a priority-granting system. ${ }^{42}$ This system grants the person who first develops a new product or process the patent rights to the invention, so long as the patent application is filed with reasonable diligence. ${ }^{43}$ Giving preference to the first and true inventor of a product or process is consistent with the rewards system of patent law and creates the incentive to invent. ${ }^{44}$

\section{B. Patentability in the United States}

Inventions' patentability within the United States is set forth in 35 U.S.C. $\S 101.45$ According to this provision, "whoever invents or discovers any new and useful process, machine, manufacture, or composition of matter, or any new and useful improvement thereof, may obtain a patent therefore, subject to the conditions and requirements of this title." 46

Three further requirements for patentability are specified in 35 U.S.C. $\$ \S$ $101,102,^{47}$ and $103:^{48}$ (1) novelty; (2) non-obviousness; and (3) utility. ${ }^{49}$ The novelty requirement precludes patents for inventions that are already known

39. RYAN, supra note 36 , at 32 .

40. Id. at 32-35. The 1952 Patent Act is completely codified in Title 35 of the United States Code. MiLleR \& DAVIS, supra note 26, at 9.

41. RYAN, supra note 36 , at 35.

42. Amy E. Carroll, A Review of Recent Decisions of the United States Court of Appeals for the Federal Circuit: Comment: Not Always the Best Medicine: Biotechnology and the Global Impact of U.S. Patent Law, 44 AM. U. L. REv. 2433, 2446-47 (1995).

43. Id. at 2447 .

44. Id.

45. Id. at 2449.

46. Id.

47. Id. 35 U.S.C. $\S 102(1988)$ states that "[a] person shall be entitled to a patent unless . .. the invention was known or used by others in this country, or patented or described in a printed publication in this or a foreign country, before the invention thereof by the applicant for patent."

48. Id. 35 U.S.C. $\S 103$ (1988) states:

[A] patent may not be obtained though the invention is not identically disclosed or described as set forth in section 102 of this title, if the differences between the subject matter sought to be patented and the prior art such that the subject matter as a whole would have been obvious at the time the invention was made to a person having ordinary skill in the art to which said subject matter pertains.

49. Id. 
and being used, or that have already been patented. ${ }^{50}$ Its purpose is to determine whether the invention is timely and original. ${ }^{51}$ The utility requirement demands that an invention be usable and serve an intended purpose that has at least a minimal social benefit. ${ }^{52}$ The test for non-obviousness turns on a determination of "prior art," or whether the subject matter of the patent deviates from common practices so as not to be self-evident. ${ }^{53}$ Generally, it involves the hypothetical judgment of a person with ordinary skill in the particular technological field. ${ }^{54}$ However, according to 35 U.S.C. $\S 102$, technologies and methods currently in use in other countries are not recognized as prior art. ${ }^{55}$ If knowledge is new for the United States, it is considered novel for the purpose of patentability. ${ }^{56}$ In addition, a written description of the method to enable the skilled person to create and use the invention is required. ${ }^{57}$ In the requirement to obtain a patent, subject matter is defined as "any new useful process, machine, manufacturer or composition of matter in any new or useful improvement thereof." not to place restrictions on subject matter for which a patent may be sought. ${ }^{59}$

\section{Biotechnology Patenting in the United States}

Since the first patent act was enacted in 1790 , only seventy of the four million U.S. patents had been issued for living organisms when Chakrabarty, a microbiologist for General Electric Co., filed for such a patent in $1972 .^{60}$ Prior to the 1980 s, the natural doctrine that organisms or substances as they occur in nature cannot be considered inventions, and are therefore not patentable, prevailed. ${ }^{61}$ This natural doctrine entirely precluded the patenting of life forms and their structural and functional components. ${ }^{62}$ Consequently, the patents for biotechnological processes and products were highly uncertain. ${ }^{63}$

This situation started to change in 1980, with the U.S. Supreme Court's decision in Diamond v. Chakrabarty. ${ }^{64}$ In Chakrabarty, the Court held

50. Id. See also 35 U.S.C. $\$ 102$.

51. STAFFLR, supra note 2, at 14.

52. Carroll, supra note 42, at 2449.

53. Id.

54. STAFFER, supra note 2 , at 14.

55. Vandana Shiva, The US Patent System Legalizes Theft and Bio-piracy (July 28, 1999), at http://www.organicconsumers.org/Patent/uspatsys.cfm (on file with author) [hereinafter Theft and Bio-piracy].
56. Id.
57. StAFfler, supra note 2, at 14.
58. Id.
59. Id.
60. DutFIELD, supra note 3, at 154.
61. Id.
62. Id.
63. Id.
64. Id. See also Czmus, supra note 1, at 437 . 
that man-made microorganisms were patentable. ${ }^{65}$ In this case, Chakrabarty invented human-made, genetically-engineered bacteria capable of breaking down multiple components of crude oil. He filed a patent application for these bacteria. $^{66}$ The capacity to break down crude oil was not possessed by any naturally occurring bacteria. ${ }^{67}$ In the patent application, Charkrabarty asserted claims to the method of producing the bacteria, the new bacteria and the bacteria themselves. ${ }^{68}$ The Court reasoned that such bacteria were patentable due to their man-made characteristics. ${ }^{69}$ The Court stated that the bacteria invented by Chakrabarty constituted a "manufacture" or "composition of matter" within the meaning of 35 U.S.C. $\S 101 .^{70}$ With this case, the Court broadened the range of patentable human-created biological products by permitting the patenting of "anything under the sun that is made by man."71

Five years after Chakrabarty, the Patent and Trademark Office (PTO) Board of Patent Appeals and Interferences held in Ex parte Hibberd, 277 U.S.P.Q. (BNA) 443 (1985), that plants also fell within the meaning of "manufacture" or "composition of matter" by confirming the holding of Chakrabarty. ${ }^{72}$ This case concerned maize plant technologies, including the development of seeds, plants, and tissue cultures that have increased free tryptophan levels, or which are capable of producing plants or seeds having increased tryptophan content. ${ }^{73}$ Such maize plants are considered to have a greater nutritional value than ordinary corns. ${ }^{74}$ The maize plants claimed in $E x$ parte Hibberd were produced through conventional cross-breeding, but they also relied on new techniques such as cell culture and genetic analysis. ${ }^{75}$ This case opened the way for the patenting of plants by holding that plants, plant seeds, and plant tissue cultures constituted patentable subject matter. ${ }^{76}$

In 1987, the PTO Board of Patent Appeals and Interferences produced another groundbreaking ruling in Ex parte Allen, 2 U.S.P.Q.2d (BNA) 1425 (1987), concerning multi-cellular animals. ${ }^{77}$ In this case, the inventors developed a method for producing polyploidy Pacific oysters. ${ }^{78}$ While such

65. Id. See also Diamond v. Chakrabarty, 447 U.S. 303 (1980).

66. Chakrabarty, 447 U.S. at 303. See also Czmus, supra note 1, at 437.

67. Chakrabarty, 447 U.S. at 303.

68. Id. at 305.

69. Czmus, supra note 1 , at 437 .

70. Chakrabarty, 447 U.S. at 307-08.

71. Czmus, supra note 1, at 439. See also Michael North, The U.S. Expansion of Patentable Subject Matter: Creating a Competitive Advantage for Foreign Multinational Companies?, 18 B.U. INT'L L.J. 111, 123 (2000).

72. DUTFIELD, supra note 3, at 156. See also Ex Parte Hibberd, 227 U.S.P.Q. (BNA) 443 (1985).

73. Ex Parte Hibberd, 227 U.S.P.Q. at 443.

74. Donald S. Chisum, Chisum on Patent 19 (2004).

75. DUTFIELD, supra note 3, at 156.

76. Id. See also CHISUM, supra note 74, at 19.

77. DutFIELD, supra note 3, at 156-57. See also Chisum, supra note 74 , at 21 .

78. Id. 
sterile oysters remain edible year round because they do not devote significant portions of their body weight to reproduction, natural oysters are considered inedible during the summer breeding season. ${ }^{79}$ Although the patent was rejected, relying on the language of the decisions in Charkrabarty and Hibberd, ${ }^{80}$ the ruling established that multi-cellular organisms were patentable. $^{81}$

Soon after, in Animal Legal Defense Fund v. Quigg, 932 F.2d 920 (Fed. Cir. 1991), the PTO announced that it would examine claims directed to multicellular organisms, including animals. ${ }^{82}$ In this case, animal rights advocate organizations, farmers, and animal husbandry organizations challenged a rule promulgated by the PTO, stating that non-naturally occurring, man-made living microorganisms, including animals, are patentable subject matter. $^{83}$ The court held that the plaintiffs lacked standing to seek judicial action of the PTO, and that non-naturally, non-human, multicellular organisms are patentable. ${ }^{84}$

In 2001, the Supreme Court finally confirmed the legality of patents on plants in J.E.M. Ag Supply Inc. v. Pioneer Hi-Bred Int'l, Inc. ${ }^{85}$ In this case, the patent holder, Pioneer Hi-Bred, sued J.E.M. Ag Supply for patent infringement. ${ }^{86}$ Pioneer Hi-Bred's patents covered the manufacture, use, sale, and offer for sale of its inbred and hybrid corn seed products. ${ }^{87}$ The reseller, J.E.M. Ag Supply, purchased the patented hybrid seeds from Pioneer Hi-Bred and resold the seeds. ${ }^{88}$ In the patent infringement suit, J.E.M. Ag Supply argued that Pioneer Hi-Bred's corn plant patent was invalid because it was outside of the scope of 35 U.S.C. $\$ 101 .^{89}$ J.E.M. argued that sexually reproducing plants were not patentable subject matter. ${ }^{90}$ The Court upheld

79. Id.

80. Id. The court of Allen stated:

The issue . . . in determining whether the claimed subject matter is patentable under Section 101 is simply whether that subject matter is made by man. If the claimed subject matter occurs naturally, it is not patentable subject matter under Section 101 . The fact, as urged by the examiner, that the oysters produced by the claimed method are controlled by the laws of nature does not address the issue of whether the subject matter is a non-naturally occurring manufacture or composition of matter. The examiner has presented no evidence that the claimed polyploidy oysters occur naturally without the intervention of man, nor has the Id. at 22 . examiner urged that polyploidy oysters occur naturally.

81. DUTFIELD, supra note 3, at 157.

82. ChISUM, supra note 74, at 22.

83. Id. See also Animal Legal Defense Fund, 932 F.2d at 920.

84. ChISUM, supra note 74 , at 22.

85. DUTFIEID, supra note 3, at 157. See also J.E.M. Ag Supply Inc., 534 U.S. at 127.

86. DutFiELD, supra note 3, at 157.

87. J.E.M. Ag Supply Inc., 534 U.S. at 127.

88. Id. at 128.

89. Id. at 129.

90. Id. 
Pioneer Hi-Bred's patent, reasoning that this method of creating new lines of plants through sexual reproduction was protectable under 35 U.S.C. $\$ 101$. $^{91}$ Conclusively, the Court in this case followed the same broad construction of 35 U.S.C. $\$ 101$ as it had done in Chakrabarty. ${ }^{92}$

\section{IMPACT OF UNITED STATES PATENTS ON LESS-DEVELOPED COUNTRIES}

\section{A. Bio-Prospecting or Bio-Piracy $?^{93}$}

Over the past two and one-half decades, there has been much debate over the issues surrounding the relationship between intellectual property rights, the appropriation of genetic resources, and the traditional or indigenous knowledge of indigenous people by developed countries. ${ }^{94}$ In general, indigenous people are defined as the descendants of pre-conquest, traditional people of a certain geographic area. ${ }^{95}$ They hold a common history, culture, language, and customary law. ${ }^{96}$ Traditional knowledge encompasses information about the agronomic or culinary characteristics of crops or the medicinal qualities of native species. ${ }^{97}$ Normally, traditional knowledge comprises insights and understandings developed through generations. ${ }^{98}$ As a result, it forms an essential aspect of an indigenous group's cultural survival. ${ }^{99}$

From the debate concerning appropriation of genetic resources and traditional or indigenous knowledge, two pivotal questions have arisen. ${ }^{100}$ First, can life be "owned"? ${ }^{101}$ Second, if it can, do corporations from developed countries have the right to own components of traditional or indigenous

91. Michael Woods, Food for Thought: The Bio-piracy of Jasmine and Basmati Rice, 13 ALB. L.J. SCI. \& TECH. 123, 129 (2002).

92. See J.E.M. Ag Supply Inc., 534 U.S. at 129-30.

93. Ghatnekar \& Ghatnekar, supra note 22.

94. Case Western Reserve University, Introduction: Bio-prospecting/Bio-piracy, at http://home.cwru.edu/ ijd3/authorship/bioprospecting.html (n.d.) (last visited Oct. 28, 2005) [hereinafter Bio-prospecting/Bio-piracy].

95. Paul Gepts, Who owns Biodiversity, and How Should the Owners Be Compensated?, 134 Plant Physiology 1295, 1303 (2004).

96. Id.

97. Id.

98. Id.

99. Id.

100. Bio-prospecting/Bio-piracy, supra note 94.

101. Id. See also Vandana Shiva, Bio-PIRAcy: The Plunder of Nature and KNOWLEDGE 19-24 (1997). 
knowledge systems of people in less-developed countries? ${ }^{102}$ Some call this phenomenon bio-prospecting, while others refer to it as bio-piracy. ${ }^{103}$

Bio-prospecting is defined as the "exploration of wild plants and animals for commercially valuable genetic and biochemical resources." 104 Bioprospecting is a fair enterprise based on certain legal conditions and benefit sharing. ${ }^{105}$ Bio-prospecting can help medical and other scientific research by collecting biological samples. ${ }^{106}$

Bio-piracy, ${ }^{107}$ on the other hand, occurs when corporations use the folk wisdom of indigenous people to locate and understand the use of medicinal plants and then exploit this knowledge commercially. ${ }^{108}$ Bio-piracy refers to the appropriation and monopolization of a traditional population's knowledge and biological resources, including the smuggling of diverse forms of plants and animals. ${ }^{109}$ Bio-piracy results in traditional populations losing control over their resources. ${ }^{110}$ While the corporations of developed countries allege that their exploitation is bio-prospecting, the less-developed countries assert that it is bio-piracy by developed countries and is an endemic and an epidemic in their lands. ${ }^{\mathrm{I} 11}$

Four case studies clearly illustrate the dispute concerning bio-prospecting or bio-piracy between developed countries and less-developed countries. These cases concern the neem tree, ${ }^{112}$ rosy periwinkle, ${ }^{113}$ basmati rice, ${ }^{114}$ and jasmine rice. ${ }^{115}$ These cases illustrate instances of the appropriation of genetic resources and traditional or indigenous knowledge of less-developed countries for

102. Bio-prospecting/Bio-piracy, supra note 94 .

103. Id. Bio-prospecting is the collection of biological materials/resources for use in scientific research, while bio-piracy refers to the unlawful use of such resources. Id. See also Kimbrell, supra note 20.

104. Ghatnekar \& Ghatnekar, supra note 22.

105. Bio-prospecting/Bio-piracy, supra note 94. But see SHIVA, supra note 101, at 72-79.

106. Michael A. Gollin, Bio-piracy: The Legal Perspective, at http://www.actionbioscience.org/biodiversity/gollin.html (Feb. 2001).

107. Bio-piracy is defined as:

1. unauthorized use of biological resources, such as plants, animals, organs, microorganisms or genes; 2 . unauthorized use of traditional communities' knowledge on biological resources; 3 . unequal share of benefits between a patent holder and the indigenous community whose resource and/or knowledge has been used; or 4. patenting of biological resources with no respect to patentable criteria (novelty, non-obviousness and usefulness).

Wikipedia, Bio-piracy, at http://en.wikipedia.org/wiki/Bio-piracy (last modified Sept. 4, 2005).

108. Kimbrell, supra note 20.

109. Ethical Boundaries, Bio-piracy in the Amazon - Introduction, at http://www.amazonlink.org/biopiracy/ (n.d.) (last visited Oct. 28, 2005).

110. Id.

111. See Theft and Bio-piracy, supra note 55.

112. See infra Part III.B.

113. Id.

114. See infra Part III.C.

115. Id. 
commercial purposes. ${ }^{116}$ These disputes have arisen mainly between the United States and less-developed countries - India, Madagascar, Pakistan and Thailand.

\section{B. Illustration 1 - Neem Tree (India) and Rosy Periwinkle (Madagascar)}

A classic example of a dispute concerning bio-piracy by corporations based in the United States is that of the Azadirachta indica, commonly known as the neem tree, in India. ${ }^{117}$ In India, there are approximately 14 million neem trees. ${ }^{118}$ Since time immemorial, the medical properties and effects of neem have been known among Indians. ${ }^{119}$ Indians have used the neem's fruits, seeds, oil, leaves, roots, and bark for medicinal purposes. ${ }^{120}$ The neem has been known to be effective for constipation, diarrhea, indigestion, nausea, malaria, fever, hemorrhoids, headaches, ear, eye and heart problems, lice, external cleansing of the body after birth, leprosy, respiratory disorders in children, rheumatism, chronic syphilitic sores, ringworm, scabies, and epistaxis. ${ }^{121}$ The neem leaves have also been used by holy men to avert bad luck and disease in India. ${ }^{122}$

When the Vedas ${ }^{123}$ were composed, the neem was called Sarva Roga Nivarini, which means "one that could cure all aliments and ills." ${ }^{24}$ Neem also has many other uses, including timber, toiletries, contraception, fuel, and

116. See Gepts, supra note 95, at 1303-04.

117. Vandana Shiva, The Neem Tree - A Case History of Bio-piracy, at http://www.twnside.org.sg/title/pir-ch.htm (n.d.) (last visited Oct. 28, 2005) [hereinafter The Neem Tree].

118. Sara Hasan, The Neem Tree, Environment, Culture and Intellectual Property, at http://www.american.edu/TED/neemtree.htm (Apr. 2002).

119. Neem Foundation, Therapeutic uses of Neem, at http://www.neemfoundation.org/thera.htm (n.d.) (on file with author) [hereinafter Therapeutic uses of Neem].

120. Id.

121. Thimmakka's, Biotechnology vs. Indigenous Knowledge: The Case of the Neem, at http://www.thimmakka.org/Newsletters/neemi.html (Jan. 1999)[hereinafter Biotechnology vs. Indigenous Knowledge].

122. Therapeutic uses of Neem, supra note 119.

123. The meaning of Vedas is defined as follows:

[O]ldest scriptures of Hinduism and the most ancient religious texts in an IndoEuropean language. The authority of the Veda as stating the essential truths of Hinduism is still accepted to some extent by all Hindus. The Veda is the literature of the Aryans who invaded NW India c. 1500 B.C. and pertains to the fire sacrifice that constituted their religion. The Vedic hymns were probably first compiled after a period of about 500 years during which the invaders assimilated various native religious ideas. The end of the Vedic period is about 500 B.C. Tradition ascribes the authorship of the hymns to inspired seer-poets (rishis).

The COLUMBIA ENCYCLOPEDIA, $\left(6^{\text {th }}\right.$ ed. 2001), available at http://www.bartleby.com/65/ve/Veda.html (2005).

124. Therapeutic uses of Neem, supra note 119. 
agriculture. ${ }^{125}$ Among its many uses, its power as a potent pesticide is the most important and controversial. ${ }^{126}$ Azadirachtin, ${ }^{127}$ one of the active ingredients in Neem, is highly effective against 200 species of insects, including mites, nematodes, fungi, bacteria, and viruses. ${ }^{128}$ Also, it is benign to most species, excluding insects. $^{129}$

Native Indians have been making pesticide emulsions for 2000 years by using their own processes. ${ }^{130}$ However, they could not patent the neem for two reasons. ${ }^{131}$ First, although an invention or process should be novel to be granted a patent, information on the neem is ubiquitous in India. ${ }^{132}$ Second, the neem is classified as a pharmaceutical because pesticides are part of agricultural processes and contribute to the health and well-being of people. ${ }^{133}$ In India, pharmaceuticals are exempt from patentability under the Indian Patent Act (IPA) of $1970 .^{134}$

However, a timber company in the United States that figured out the neem tree's usefulness in acting as a pesticide patented its process to stabilize emulsions and sold the patent to the U.S.-based company, W.R. Grace, in 1971. ${ }^{135}$ W.R. Grace secured its rights to the formula of a pesticide by using the emulsion from the neem tree's seeds, and began suing Indian companies for making the emulsion. ${ }^{136}$ Among the patents on neem, the patents granted to W.R. Grace for extraction and storage processes are the most controversial. ${ }^{137}$

125. Hasan, supra note 118.

126. Id.

127. Azadirachtin is a naturally occurring substance that belongs to an organic molecule class called tetraortritenoids. Pioneer Enterprise, Azadirachtin, at http://www.pioneerherbs.com/azadirachtin.htm (2000). Azadirachtin is structurally similar to ecysones that control the process of metamorphosis of insects. Id. It occurs in all parts of the neem tree but the majority of it is concentrated in the neem kernel. Id. As a chemical compound belonging to limonoids, it is known to affect over 200 species of insect by acting as an antifeedant and growth disruptor. Wikipedia, Azadirachtin, at http://en.wikipedia.org/wiki/Azadirachtin (last modified July 31, 2005).

128. Biotechnology vs. Indigenous Knowledge, supra note 121.

129. Id.

130. Hasan, supra note 118.

131. Biotechnology vs. Indigenous Knowledge, supra note 121.

132. Id.

133. Id.

134. Id. Since 1970 , India had a patent law that was regarded as a model by many other less-developed countries. Amit Sen Gupta, Indian Patent Act-Jeopardising the Lives Millions, at http://phm-india.org/issues/patents/indianpatent.html (n.d.) (on file with author). The Indian patent law stressed on the obligations of the patent holder by providing strong provisions that prevented the patent holder's monopoly rights. Id. Particularly, Indian patent law did not provide for monopoly rights for drugs and agro-chemicals. Id. As a result, the Indian drug industry became the strongest and the most self-reliant industry in less-developed countries. Id.

135. Hasan, supra note 118.

136. Id.

137. Id. 
First, U.S. Patent No. $4,946,681^{138}$ was granted in 1990 for improving the storage stability of neem seed extracts containing azadirachtin. ${ }^{139}$ Second, U.S. Patent No. 5,124,349 $9^{140}$ was granted in 1994 for storage of stable insecticidal composition comprising neem seed extract. ${ }^{141}$ This patent mainly contributed to increase "the shelf-life stability of azadirachtin solution."

W.R. Grace alleged that azadirachtin was being destroyed during traditional processing, thus its method for making stable emulsion was novel. ${ }^{143}$ However, the Indians asserted that W.R. Grace's allegation was inaccurate ${ }^{144}$ and argued that the extracts were subject to degradation, but this was not a problem since Indian farmers usually put such extracts to use as they need them. ${ }^{145}$ According to them, the method of stabilization patented by W.R. Grace was needed only in order for the product to be packaged and shipped for an extended period of time in the commercial market. ${ }^{146}$ Indians argued that this stabilization and other advanced methods to make stable emulsion had already been developed by Indian scientists in the 1960s and 1970s. ${ }^{147}$

Also, they argued the patent claims to neem were illegitimate, basing their argument on two grounds. ${ }^{148}$ First, Indians claimed nature's creativity and the creativity of other cultures as its own. ${ }^{149}$ Second, it led to the false claim that the pesticide property of neem was created by the patentee, although this

138. Id.

A process for the production of stable azadirachtin solutions comprising extracting ground neem seeds with a solvent having azadirachtin solubility to produce an aqueous-containing azadirachtin extract solution and then adding an effective amount of 3-4 Angstrom molecular sieves to selectively remove water from the extract to yield a storage-stable azadirachtin solution having less than $5 \%$ water by volume.

U.S. Patent No. 4,946,681 (issued Aug. 7, 1990).

139. Hasan, supra note 118. The inventor is named as James F. Walter of Ashton, Maryland. Id.

140. Id.

Storage stable pesticide compositions comprising neem seed extracts which contain azadirachtin as the active pesticidal ingredient wherein the compositions are characterized by their non-degrading solvent systems. In a first embodiment, the pesticide compositions contain solvent systems characterized as having greater than $50 \%$ by volume aprotic solvents and less than $15 \%$ by volume water. In a second embodiment, the pesticide compositions contain solvent systems characterized as having greater than $50 \%$ by volume alcohol and less than $5 \%$ by volume water. The pesticide compositions contain surfactant concentrations of at least about $1.0 \%$, up to $10 \%$.

U.S. Patent No. 5,124,349 (issued Jun. 23, 1992).

141. Hasan, supra note 118.

142. Id.

143. The Neem Tree, supra note 117.

144. Id. See also Hasan, supra note 118.

145. The Neem Tree, supra note 117.

146. Id.

147. Id.

148. SHIVA, supra note 101 , at 71 .

149. Id. 
patent was based on traditional knowledge of Indians. ${ }^{150}$ Indians claimed W.R. Grace's patent claim treated petty tinkering as a source of creation, rather than acknowledging that specific species were sources of creation and communities were sources of knowledge. ${ }^{151}$

W.R. Grace claimed that their neem patents and project benefited the Indian economy by providing employment opportunities and high remuneration to the farmers because the price of neem seeds had increased. ${ }^{152}$ Over the last twenty years, the per ton price of neem seed increased more than ten times. ${ }^{153}$ However, contrary to W.R. Grace's claim, this increase in the price of neem seeds turned a free resource into an exorbitantly expensive one, producing a negative result. ${ }^{154}$ The local Indian farmers are now competing with an industry supplying consumers in developed countries. ${ }^{155}$ Since the Indian farmers cannot afford the price that the industry can, the industry will ultimately have exclusive access to neem trees as a raw material and to all production processes. $^{156}$

Another instance of a dispute concerning bio-piracy by corporations is the rosy periwinkle case. ${ }^{157}$ In 1954, following clues from indigenous medicine men in Madagascar, researchers at Eli Lilly pharmaceuticals extracted two powerful cancer-fighting alkaloids from the rosy periwinkle: vinblastine and vincristine. ${ }^{158}$ These anticancer compounds are especially effective against leukemia and Hodgkin's disease. ${ }^{159}$ Eli Lilly first became aware of the effect of the rosy periwinkle because of its traditional use as an anti-diabetic. ${ }^{160}$ Eli Lilly made hundreds of millions of dollars from drugs derived from the rosy periwinkle alkaloid. ${ }^{161}$ However, the people of Madagascar who provided the indigenous knowledge about the rosy periwinkle never received any compensation from Eli Lilly. ${ }^{162}$

150. Id.

151. Id.

152. The Neem Tree, supra note 117.

153. Id. W.R. Grace said that the price of neem seed has gone up from Rs 300 a ton to current levels of Rs $3000-4000$ a ton over the last twelve years. Id. In fact, however, the price has risen more than this. Id. The price has been risen to over Rs 8000 (approximately $\$ 300$ ) per ton. Id.

154. Id.

155. Id.

156. Id.

157. See Case Westem Reserve University, Case Study: Rosy Periwinkle (Madagascar), at http://home.cwru.edu/ ijd3/authorship/rosy.html (2003) [hereinafter Rosy Periwinkle].

158. Id. See also Elizabeth John \& K.T. Chelvi, Bio-piracy and the Law of the Jungle, NEW STRATT TIMES PRESS, June 27, 2004, available at http://www.williams.edu/go/native/malaysia.htm (last visited Oct. 28, 2005).

159. Kate Wong, Mother Nature's Medicine Cabinet (Apr. 9, 2001), at http://viennadoctor.com/ENG/Article_ENG/natures-medicine-cabinet.html (on file with author).

160. Rosy Periwinkle, supra note 157.

161. John \& Chelvi, supra note 158. See also Rosy Periwinkle, supra note 157.

162. John \& Chelvi, supra note 158. 


\section{Illustration 2 - Basmati Rice (India and Pakistan) and Jasmine Rice} (Thailand)

The above cases regarding patents using traditional knowledge of indigenous people in less-developed countries are not unique. ${ }^{163}$ There is another issue between developed countries and less-developed countries regarding rice, with the exploited countries being mostly in Asia. ${ }^{164}$ Rice is the basic food in all meals in Asia; it constitutes nearly eighty percent of people's daily caloric intake. ${ }^{165}$ Rice accounts for up to half of Asian farms' incomes. ${ }^{166}$ Over thousands of years in Asia's agricultural history, farmers developed and conserved an enormous amount of genetic diversity in rice. ${ }^{167}$ However, these countries - mostly less-developed countries - did not provide patent protection for their varieties of rice. ${ }^{168}$

Seeing the international market potential of this local genetic diversity of rice, agricultural biotechnology companies in developed countries acquired samples of rice, then genetically engineered a close substitute for the natural variety maintaining its desirable consumer characteristics. ${ }^{169}$ The modified varieties can be patented, and their names copyrighted under TRIPS. ${ }^{170}$ It means that the biotechnology companies can license the production of rice in specified countries, export the product in competition with the natural varieties from those countries, and further prevent the natural varieties from being sold in importer's markets using its traditional names. ${ }^{171}$ Examples of products that have been involved in this scenario are basmati rice from India and jasmine rice from Thailand. ${ }^{172}$

In 1997, a Texas-based company, RiceTec Inc., won a controversial U.S. patent ${ }^{173}$ on basmati rice. ${ }^{174}$ RiceTec got a patent for three things - growing

163. See supra Part III.B.

164. See Matthew Clement, Rice Imperialism: The Agribusiness Threat to Third World Rice Production, MONTHLY REVIEW, (Feb. 2004), available at http://www.monthlyreview.org/0204clement.htm (last visited Oct. 28, 2005). See also GRAIN, Bio-piracy, TRIPS and the Patenting of Asia's Rice Bowl: A Collective NGO Situationer on IPRs on Rice, (May 1998), at http://www.grain.org/briefings/?id=29 (last visited Oct. 28, 2005) [hereinafter Patenting of Asia's Rice Bowl].

165. Patenting of Asia's Rice Bowl, supra note 164.

166. Id.

167. Id.

168. William A. Kerr, Jill E. Hobbs \& Revadee Yampoin, Intellectual Property Protection, Biotechnology, and Developing Countries: Will the TRIPs be Effective? AgBioForum, 2(384), 203-211 (1991), at http://www.agbioforum.org/v2n34/v2n34a09-kerr.htm (1999).

169. Id.

170. Id.

171. Id.

172. Id.

173. RAFI, Basmati Rice Update, (Jan. 4, 2000), http://www.biotechinfo.net/basmati_rice.html (last visited Oct. 28, 2005) [hereinafter Basmati Rice Update].

The invention relates to novel rice lines and to plants and grains of these lines 
rice plants with certain characteristics identical to basmati; the grain produced by such plants, and the method of selecting the rice plant based on a starch index (SI) test devised by RiceTec. ${ }^{175}$

Basmati rice means "queen of fragrance" or "the perfumed one."176 Basmati rice has been grown for centuries in India and Pakistan, and basmati rice varieties are recognized worldwide for their fragrant aroma, long and slender grain, and distinctive taste. ${ }^{177}$ For this reason, basmati rice has been known as the "crown jewel" of South Asian rice ${ }^{178}$ and has been favored by emperors and praised by poets for hundreds of years. ${ }^{179}$ For a long time, basmati export markets have been important for India and Pakistan. ${ }^{180}$ In 1998 and 1999, basmati exports were valued at approximately $\$ 425$ million in India. ${ }^{181}$ RiceTec had been trying to enter the international rice market with brand names such as Kasmati and Texmati to describe basmati-type rice, but it did not succeed. ${ }^{182}$ However, after RiceTec was granted a patent in 1997, it was able to call its aromatic, various forms of basmati rice "Basmati" within the United States. ${ }^{183}$ In addition, RiceTec labeled its rice "Basmati" when exporting it. ${ }^{184}$ The patent of RiceTec applies to breeding crosses involving twenty-two farmer-bred basmati varieties from Pakistan and India. ${ }^{185}$ Although this patent is valid only in the United States, it affects extensively varieties

and to a method for breeding these lines. The invention also relates to a novel means for determining the cooking and starch properties of rice grains and its use in identifying desirable rice lines. Specifically, one aspect of the invention relates to novel rice lines whose plants are semi-dwarf in stature, substantially photoperiod insensitive and high yielding, and produce rice grains having characteristics similar or superior to those of good quality basmati rice. Another aspect of the invention relates to novel rice grains produced from novel rice lines. The invention provides a method for breeding these novel lines. A third aspect of the invention relates to the finding that the "starch index" (SI) of a rice grain can predict the grain's cooking and starch properties, to a method based thereon for identifying grains that can be cooked to the firmness of traditional basmati rice preparations, and to the use of this method in selecting desirable segregants in rice breeding programs.

U.S. Patent No. 5,663,484 (issued Sept. 2, 1997).

174. Basmati Rice Update, supra note 173. See also Anthony Browne, India Fights U.S. Basmati Rice Patent, at http://www.biotech-info.net/basmati_patent.html (Jun. 25, 2000).

175. TED Case Studies - Basmati, available at http://www.american.edu/projects/mandala/TED/basmati.htm (n.d.) (last visited Oct. 28, 2005). [hereinafter TED Case Studies - Basmati].

176. Id.

177. Id.

178. Basmati Rice Update, supra note 174.

179. TED Case Studies - Basmati, supra note 175.

180. See Etc group, Update on Basmati Rice Patent, at http://www.etcgroup.org/article.asp?newsid=34 (Jan. 4, 2000)[hereinafter Update on Basmati Rice Patent].

181. Id.

182. TED Case Studies - Basmati, supra note 175.

183. Id.

184. Id.

185. Update on Basmati Rice Patent, supra note 180. 
grown anywhere in the Western Hemisphere. ${ }^{186}$ Also, this has repercussions for India and Pakistan, not only because India and Pakistan will lose the 45,000 ton U.S. import market, but also because its position will be threatened in crucial markets like the European Union, the United Kingdom, the Middle East, and West Asia. ${ }^{187}$

The U.S. import market forms ten percent of the total basmati export of India and Pakistan. ${ }^{188}$ From 1996 to 1997, India exported approximately 523,000 tons of Basmati to the European Union. ${ }^{189}$ If RiceTec's patent is not revoked, and RiceTec can sell its rice under the brand name "Basmati," it will definitely cut into India and Pakistan's global market share. ${ }^{190}$ According to Vandana Shiva, director of a Delhi-based research foundation monitoring issues of patents and bio-piracy, RiceTec's patent on basmati rice constituted theft in three ways:

a theft of collective intellectual and biodiversity heritage of Indian farmers, a theft from Indian traders and exporters whose markets are being stolen by RiceTec Inc, and finally a deception of consumers since RiceTec is using a stolen name Basmati for rice which are derived from Indian rice but not grown in India and, hence are not the same quality. ${ }^{191}$

The same situation occurred with Thai jasmine rice. ${ }^{192}$ A University of Florida researcher, Chris Deren, developed a new strain of jasmine rice. ${ }^{193}$ Thai jasmine rice is indigenous to Thailand, but it is not well-suited to the United States because of the day length. ${ }^{194}$ To get the rice to grow in the United States, Deren used gamma rays to genetically alter the plants so they would be nonresponsive to day length. ${ }^{195}$ Also, he manipulated the rice to grow shorter than traditional Thai jasmine plants to make them suitable for machine harvest. ${ }^{196}$

Although Thailand is the world's largest exporter of rice, the prospect of a U.S. patent on jasmine rice produced widespread alarm in the Thai rice

186. Id.

187. TED Case Studies - Basmati, supra note 175.

188. Id.

189. Id.

190. Id.

191. Id.

192. See Danielle Knight, Groups Take Legal Action to End U.S. 'Bio-piracy': Legal Action on Basmati \& Jasmine Rice, (Apr. 27, 2000), at http://www.grain.org/bio-ipr/?id=166 (last visited Oct. 28, 2005).

193. See Paul Kimpel, Gourmet-Style Thai Jasmine Rice May Be Future U.S. Crop (Sept. 11, 2001), at http://news.ufl.edu/2001/09/11/jasmine (last visited Oct. 28, 2005). See also Noel Rajesh, And now, Thai Jasmine Rice, at http://www.indiatogether.org/agriculture/articles/noel_jasmine.htm (Aug. 2002).

194. Kimpel, supra note 193.

195. Id.

196. Id. 
industry. ${ }^{197}$ In 2000 , Thailand exported 243,000 tons of rice to the United States, its biggest buyer, and jasmine rice amounted to 200,000 tons. ${ }^{198}$ If the small-scale farmers in Thailand lose the jasmine rice markets, in particular, to their main buyer, the United States, the basis of their livelihood will undoubtedly be threatened. ${ }^{199}$ An American strain of jasmine rice under the control of large companies would certainly seriously undercut Thailand's rice market. ${ }^{200}$

According to the general manager of Semi-Chi Rice Produces, an American company in Florida, a jasmine rice variety that is comparable to jasmine rice imported from Thailand can bring in a sizeable profit. ${ }^{201}$ Currently, regular varieties of American rice sell at $\$ 340$ per ton, while jasmine rice from Thailand sells at $\$ 520$ per ton. ${ }^{202}$ In 2001, Thai jasmine rice sales in the United States amounted to about $\$ 120$ million dollars. ${ }^{203}$ If this $\$ 120$ million dollar market is reduced, it would have a drastic effect on the Thai rice export, and it would certainly hit Thai farmers the hardest. ${ }^{204}$ As a result of this controversy over jasmine rice, Thai farmers and citizens carry negative feelings toward the United States. ${ }^{205}$

\section{SETTLEMENT OF THE DISPUTE UNDER TRIPS}

The conflict between developed and less-developed countries over the enforcement of intellectual property rights was an increasingly divisive legal issue through the later twentieth century. ${ }^{206}$ In the case of basmati rice, Indians argued the U.S. government's decision to grant a patent for the basmati rice violated TRIPS. ${ }^{207}$ They said the basmati rice is traditionally grown in India and Pakistan, and granting a patent over it violated the geographical indications act under TRIPS. ${ }^{208}$ Geographical indication is the identification of "a good originating in the territory of a member, or a region or locality in that territory,

197. BizAsia, Thai-U.S. Conflict over Jasmine Rice (Oct. 26, 2001), at http://bizasia.com/agricultrue_/epz2q/thai_us-conflict-jasmine.htm (on file with author).

198. Chris Westcott, Thai Jasmine Rice and the Threat of the US Biotech Industry (Dec. 18, 2001), http://www.mofga.org/news200201 19.html (last visited Oct. 28, 2005) [hereinafter Thai Jasmine Rice].

199. Id.

200. Id.

201. Id.

202. Id.

203. Id.

204. Id.

205. Id. Thailand, it is now a common sight to see farmers wearing Bin Laden $\mathrm{t}$-shirts during their protests. Id. The protests are increasingly becoming aggressively anti-American. Id. Most farmers do not support the violent acts of September $11^{\text {th }}$, but many of them sympathize with Bin Laden's anti-American sentiments. Id.

206. Doris Estelle Long, The Impact of Foreign Investment on Indigenous Culture: An Intellectual Property Perspective, 23 N.C.J. INT'L L. \& COM. REg. 229, 235 (1998).

207. TED Case Studies - Basmati, supra note 175.

208. Id. 
where a given quality, reputation, or other characteristic of the good is essentially attributable to its geographical origin."209 "Scotch whiskey" and "French champagne" are well-known examples. ${ }^{210}$ Indians argue that the United States cannot label their rice "Basmati," just as their wine cannot be labeled "champagne."211

Although over 111 countries agreed on TRIPS, disputes regarding global bio-piracy and the efforts to settle those disputes have continued. ${ }^{212}$ Each country has its own position; the developed countries and the less-developed countries disagree over whether a strict patent system on less-developed countries should be imposed. ${ }^{213}$ The United States supports an international agreement which imposes a strict patent system on less-developed countries, ${ }^{214}$ while less-developed countries protest it. ${ }^{215}$

This section will present potential solutions to settle the dispute concerning bio-piracy issues between developed countries, specifically the United States and less-developed countries.

\section{A. TRIPS}

In 1883, the first global agreement on patent laws was signed in the Paris Convention. ${ }^{216}$ This convention had two fundamental provisions for current international intellectual property agreements. ${ }^{217}$ The first provision is the principle of national treatment that demands the member countries not discriminate against foreign property owners. ${ }^{218}$ The second provision is the right of priority that permits a party filing a patent in a member country to receive that same filing date in subsequent application in other member states. $^{219}$ The Paris Convention initially attempted to establish a global framework for patent law. ${ }^{220}$ However, this attempt failed because for over eighty years after the Convention, there was no international body to oversee the enforcement of its provisions. ${ }^{221}$

However, from 1967, World Intellectual Property Organization (WIPO), a special agency of the United Nations, began to administer several

209. Id.

210. Update on Basmati Rice Patent, supra note 180.

211. Id. at 210.

212. Long, supra note 206, at 236.

213. See Leanne M. Fecteau, Note, The Ayahuasca Patent Revocation: Raising Questions About Current U.S. Patent Policy, 21 B.C. THIRD WORLD L.J. 69, 77 (2001).

214. Id.

215. See id.

216. Carroll, supra note 42, at 2456.

217. Id.

218. RYAN, supra note 36, at 94. See also Carroll, supra note 42, at 2456.

219. Id.

220. Id. at 2457.

221. Id. 
international intellectual property agreements ${ }^{222}$ including the Paris Convention. ${ }^{223}$ WIPO receives applications once a national patent is filed, publishes reports about national patents, and initiates patent registration procedures in other countries. ${ }^{224}$ Also, one of the main functions of WIPO is to resolve procedural discrepancies among the domestic patent systems of member countries. ${ }^{225}$ Such procedural discrepancies became apparent when comparing the United States patent filing system with the filing systems in other countries. ${ }^{226}$ While the United States grants priority filing status to proven inventors of patentable items, almost every other country bases its patent priority on the filing date of the patent application. ${ }^{227}$ Since in many of the latter, first-to-file jurisdictions, publication of an inventor's discovery precludes the inventor from obtaining a patent on his or her invention, problems arise in trying to harmonize these two systems. ${ }^{228}$

Although WIPO's efforts to resolve procedural discrepancies between member countries seemed to succeed, questions have since been raised as to its effectiveness. ${ }^{29}$ While WIPO held the position to oversee international intellectual property systems, it had no enforcement mechanism to assure that a member's laws complied with the minimum requirements. ${ }^{230}$ While lessdeveloped countries regarded WIPO as a hospitable forum for their concerns, developed countries considered it to be indifferent to their needs. ${ }^{231}$ Developed countries, including the United States, claimed that WIPO did not promote more stringent intellectual property systems among its member countries. ${ }^{232}$ They asserted that the standards of the Paris Convention adopted by WIPO were too weak to provide adequate international patent protection. ${ }^{233}$ They pointed out the situation where the less-developed countries had become important sources of the production of intellectual property products, and much of production was pirated. ${ }^{234}$ Under the standards of the Paris Convention, even in member countries that belonged to the patent treaty, local laws offered

222. Id. The lists of international agreements on intellectual property rights administered by WIPO are: Berne Convention, dealing with copyrights; Madrid and Lisbon Agreements, dealing with repression of false or deceptive indications of source on goods, and protection and registration of appellations of origin, and the Rome Convention, dealing with performers, producers of phonograms, and broadcasting organizations. Id.

223. Id.

224. Id.

225. Id.

226. Id.

227. Id.

228. Id.

229. Id.

230. Doris Estelle LoNg \& ANTHONy D'Amato, A Coursebook In INTERNATIONAL INTELLECTUAL PROPERTY 135 (2000).

231. Id.

232. Carroll, supra note 42 , at 2458.

233. RYAN, supra note 36 , at 104.

234. Id. 
little chance of remedy for infringement. ${ }^{235}$ Developed countries realized that they could not prevent their developed intellectual property products from being pirated under WIPO. ${ }^{236}$

Since many developed countries questioned the effectiveness of WIPO, a new alternative proposal was needed. ${ }^{237}$ The alternative is the Uruguay Round of the General Agreement on Tariffs and Trade (GATT) ${ }^{238}$ To reform the international intellectual property institutions, the United States established the Advisory Committee on Trade Policy and Negotiation (ACTPN), ${ }^{239}$ led by the CEOs of Pfizer and IBM. ${ }^{240}$ The ACTPN persuaded the United States Trade Representative (USTR) that multilateral trade negotiations should be used to adapt the institution to a world economy in which less-developed countries were major producers of intellectual property goods and developed countries owned the intellectual property rights of goods produced by less-developed countries. ${ }^{241}$ The ACTPN contended patent protection regulations should be harmonized at a high standard to protect the intellectual property rights of developed countries and prevent patent infringement by less-developed countries. ${ }^{242}$ Consequently, persuaded by U.S. business interests, the USTR constructed a GATT strategy. ${ }^{243}$ Before 1986, a Ministerial Declaration was issued in Geneva, and the new GATT round, the Uruguay Round, began. ${ }^{244}$ As a result of this Declaration, TRIPS was included in the GATT. ${ }^{245}$

235. Id.

236. See id.

237. See Carroll, supra note 42, at 2459.

238. Id.

239. RYAN, supra note 36 , at 105 . The ACTPN was established by the 1979 Trade Act to institutionalize business advice to the president. Id.

240. Id.

241. See id.

242. Id. See also infra note 245.

243. RYAN, supra note 36 , at 105 . The main concern of the GATT rounds of negotiations in the 1950s was tariff reduction. Id. An "offer-concession" negotiation scheme was developed. Id. Under this scheme, the major trading states bargained in an essentially bilateral fashion, requesting and offering concessions, trading off agreements in one product area for those in another. Id. In the Kennedy Round of tariff negotiations in the 1960s, a "linear-cut" negotiation scheme whereby an across-the-board cut was the starting point for exceptionsoriented bargaining. Id. In the Tokyo Round from 1973 to 1979 , a multilateral trade negotiations forum proved capable of winning international agreements to reduce nontariff trade barriers. Id. Nontariff barriers were unreasonable customs procedures, import-licensing schemes, and export subsidies that posed special challenges to trade negotiations because they were difficult to quantify and, thus, tricky to value and weigh when offers and concessions were being made. $I d$.

244. Carroll, supra note 42, at 2459. The Ministerial Declaration, written by the Swiss and Colombian ambassadors, gave the following mandate to the negotiators:

In order to reduce the distortions and impediments to international trade, and taking into account the need to promote effective and adequate protection of intellectual property rights, and to ensure that measures and procedures to enforce that measures and procedures to enforce intellectual property rights do not themselves become barriers to legitimate trade, the negotiations shall aim to clarify GATT provisions and elaborate, as appropriate, new rules and disciplines. 
TRIPS is the most recent, and most comprehensive, multinational treaty dealing with the protection of traditional intellectual property. ${ }^{246}$ The purpose of TRIPS is "to reduce distortions and impediments to international trade [by] taking into account the need to promote effective and adequate protection of intellectual property rights and to ensure that measures and procedures to enforce intellectual property rights do not themselves become barriers to legitimate trade...."247 In other words, TRIPS sets out the minimum standards of protection to be provided by each member country. ${ }^{248}$ TRIPS adopts the long-established, minimum substantive norms established in the Berne Convention for the Protection of Literary and Artistic Work, ${ }^{249}$ governing copyrights, and the Paris Convention for the Protection of Industrial Property, ${ }^{250}$ governing patents, and trademark. ${ }^{251}$ TRIPS includes provisions

Negotiations shall aim to develop a multilateral framework of principles, rules and disciplines dealing with international trade in counterfeit goods, taking into account work already undertaken in the GATT. These negotiations shall be without prejudice to other complementary initiatives that may be taken in the WIPO and elsewhere to deal with these matters.

GERVAIS, supra note 25 , at 11 .

245. Carroll, supra note 42, at 2459. The TRIPS agreement was signed into United States law by President Clinton in December 1994 as part of the Uruguay Round. Id. at 2460.

246. Long, supra note 206, at 249-50.

247. Fecteau, supra note 213 , at 77.

248. Id. at 78. See also World Trade Organization, TRIPS: A More Detailed Overview of the TRIPS Agreement, at http://www.wto.org/english/tratop_e/trips_e/intel2_e.htm (n.d.) (last visited Oct. 28, 2005).

249. Long, supra note 206, at 250. Berne Convention for the Protection of Literary and Artistic Works was signed in 1886 . RYAN, supra note 36 , at 100 . Since being signed, it has been amended many times. Id. WIPO's International Bureau that receives financial assessments from member countries and charges fees for the services, administers the Berne Convention. Id. The Beme Convention required members to grant the identical level of protection to domestic and foreign intellectual property owners, like many other multinational and bilateral treaties. Long, supra note 206, at 250. However, the Berne Convention did not merely require establishing minimum substantive standards of protection that members were required to meet in their domestic laws. Id. at 252 . The Convention currently requires copyright protection for literary and artistic works including every production in the literary, scientific and artistic domain whatever may be the mode or form of its protection. Id. It requires that authors be granted a term of protection of no less than the life of the author, plus fifty years, for their copyrighted works. Id. Also, the authors should be given the right to control the reproduction of their works, their translation and their public distribution, performance and display under the Convention. Id. The United States acceded to the Convention in 1989. Id.

250. Long, supra note 206, at 250 . The Paris Convention for the protection of industrial property was signed in 1883 and periodically amended in the twentieth century. RYAN, supra note 36, at 94 . Instead of obligating minimum standards of patent protection among its members, each Paris Union member freely offers any standard of patent protection it wishes. Id. However, the Convention requires national treatment that demands members not discriminate against foreign property owners. Id. The Paris Convention requires members to provide patent owners a right of priority one year from the date of national filing in which to file patent applications in members; independence of existence so that forfeiture of a patent in one country does not result in world-wide forfeiture, and the right of the inventor as such in the patent. Long, supra note 206, at 254.

251. Long, supra note 206, at 250. 
protecting a broad range of intellectual property rights, including patents, copyrights, trademarks, geographical indications, and industrial designs. ${ }^{252}$ TRIPS patent provisions allow a twenty-year term of protection from the time of filing and define patentable subject matter as any new development that involves an inventive step and an industrial application. ${ }^{253}$ In addition, TRIPS strengthens international patent protections by prohibiting discrimination against foreign patents. ${ }^{254}$ While guaranteeing strengthened patent protections to all member countries, TRIPS includes provisions that exclude certain subject matter from patentability for a limited time, such as products that protect human, plant, or animal life and health, or products that are harmful to the environment. ${ }^{255}$

The provisions of TRIPS mirror the U.S. patent requirements of novelty, non-obviousness, and utility. ${ }^{256}$ Also, the TRIPS Agreement stated that the World Trade Organization (WTO) Council for TRIPS would monitor compliance with TRIPS provisions and oversee disputes between member countries. ${ }^{257}$ The WTO Council has resolved patent enforcement problems that existed before trade sanctions were imposed. ${ }^{258}$ However, it tends to pass resolutions in favor of developed countries. ${ }^{259}$

For instance, India and Pakistan failed to comply with the requirement of enacting an intellectual property law system. ${ }^{260}$ TRIPS required these countries to pass new patent legislation that conformed to TRIPS requirements and to set up mailbox systems for holding applications. ${ }^{261}$ The applications in the mailbox would receive priority dates as of the dates they were originally submitted if these countries enacted a patent system complying with TRIPS. ${ }^{262}$ When India and Pakistan failed to comply with the mailbox requirement under TRIPS, the United States filed dispute resolution proceedings through the WTO Council against each country. ${ }^{263}$ When Pakistan complied with this requirement, the United States dropped its complaint. ${ }^{264}$ Also, the WTO Appellate Body upheld a panel ruling in favor of the United States against India, thereby making India follow mailbox rule obligations, despite significant domestic opposition. ${ }^{265}$

252. Carroll, supra note 42 , at 2460.

253. Id.

254. Id.

255. Id.

256. Fecteau, supra note 213 , at 78.

257. Id.

258. Id.

259. See id.

260. Id.

261. Id. at 79 .

262. Id.

263. Id.

264. Id.

265. Id. 
In creating a system granting patents on agricultural and pharmaceutical products, India complied with TRIPS Article 27. ${ }^{266}$ However, this requirement does not take into account the differing cultural perspectives of indigenous groups in member countries regarding the modification of biological resources, particularly, discovering and nurturing the medicinal and agricultural uses of plants over the centuries. ${ }^{267}$ Nevertheless, less-developed countries were economically pressured by developed countries to sign TRIPS, preventing them from passing protectionist laws. ${ }^{268}$ Consequently, TRIPS Article 27 directly opposes CBD's goals of protecting the genetic resources of less-developed countries. $^{269}$

\section{B. Convention on Biological Diversity}

The CBD was first presented at the United Nations Conference on Environment and Development (UNCED), ${ }^{270}$ which took place in Rio de Janeiro in June 1992. ${ }^{271}$ It came into force in 1993 and has 182 contracting parties. ${ }^{272}$ According to international environmental concerns at UNCED, the CBD specifically focused on conversations about the Earth's biological diversity and its sustainability through national strategies, plans, and programs. $^{273}$ In the CBD, intellectual property rights were addressed in three

266. Id. at 80 . TRIPS Article 27 states that member countries must protect property rights in genetic plant resources "either by patents or by an effective sui generis system or by any combination thereof." Id.

267. Id. at 81 .

268. Id.

269. Id.

270. Carroll, supra note 42 , at 2461 . This conference is commonly referred to as the "Earth Summit" or the "Rio Summit." Id. UNCED was unprecedented for a UN conference, both in terms of its size and the scope of its concern. United Nations, UN Conference on Environment and Development (1992), at http://www.un.org/geninfo/bp/enviro.html (May 23, 1997) Twenty years after the first global environment conference, the UN sought to help countries reconsider economic development and halt the destruction of natural resources and pollution of the earth. Id. The main messages of this conference were as followings:

1. Patterns of production-particularly the production of toxic components, such as lead in gasoline, or poisonous waste-are being scrutinized in a systematic manner by the UN and governments alike;

2. Alternative sources of energy are being sought to replace the use of fossil fuels which are linked to global climate change;

3. New reliance on public transportation systems is being emphasized in order to reduce vehicle emissions, congestion in cities and the health problems caused by polluted air and smog;

4. There is much greater awareness of and concern over the growing scarcity of water.

Id.

271. Carroll, supra note 42 , at 2461-62.

272. DUTFIELD, supra note 3, at 212.

273. Carroll, supra note 42 , at 2462.

CBD's overall objectives are: the conservation of biological diversity, the sustainable use of its components and the fair and equitable sharing of the 
separate articles relating to indigenous peoples. ${ }^{274}$ The first article sets forth "the aim of sharing in a fair and equitable way the results of research and development and the benefits arising from the commercial and other utilization of genetic resources." 275 The second article concerns "access to and transfer of technology which makes use of those resources, on mutually agreed upon terms, including technology protected by patents and other intellectual property rights" to less-developed countries. ${ }^{276}$ The third article stated that developed countries must "take all practicable measures to promote and advance priority access on a fair and equitable basis ... to the results and benefits arising from biotechnologies" when based upon genetic resources provided by lessdeveloped countries. ${ }^{277}$ Since many indigenous communities are dependent on biological resources, less-developed countries support the CBD. ${ }^{278}$

\section{TRIPS, Article 27.3(b); Traditional Knowledge and Biodiversity}

Among Articles in the TRIPS agreement, Article 27 defines which inventions governments should make eligible for patenting and what they can exclude from patenting. ${ }^{279}$ Specifically, Article $27.3(\mathrm{~b})^{280}$ focuses on biotechnological inventions. ${ }^{281}$ It is under review in WTO Council, as required

benefits arising out of the utilization of genetic resources, including by appropriate access to genetic resources and by appropriate transfer of relevant technologies.

STAFFLR, supra note 2 , at 28.

274. Carroll, supra note 42, at 2462.

275. Id.

276. Id.

277. Id. U.S. President George [Insoon, please insert the appropriate middle initial to make clear which President George Bush.] Bush refused to sign the Convention on Biological Diversity, reasoning that if the United States biotech industry was forced to disclose secrets or give away products, its incentive to invent would be lost. Id. at 2963. Many biotech-related firms and groups in the United States praised President Bush's refusal to sign. Id. However, due to the pressures from international environmental groups, Madeleine Albright, U.S. Representative to the UN, signed the Convention. Id.

278. See Agenda for Change, Convention on Biological Diversity, at http://www.iisd.org/rio+5/agenda/biodiversity.htm (n.d.) (last visited Oct. 28, 2005).

279. World Trade Organization, TRIPS: Reviews, Article 27.3(B) and Related Issues, Background and The Current Situation, at http://www.wto.org/english/tratop_e/trips_e/art27_3b_background_e.htm (last modified Jun. 24, 2004)[hereinafter TRIPS: Reviews, Article 27.3(B)].

280. Id. Article 27.3(b) states:

Members may exclude from patentability (b) plants and animals other than micro-organisms, and essentially biological processes for the production of plants or animals other than non-biological and microbiological processes. However, Members shall provide for the protection of plant varieties either by patents or by an effective sui generic system or by any combination thereof. The provisions of this subparagraph shall be reviewed four years after the date of entry into force of the WTO Agreement.

GERVAIS, supra note 25, at 217-18.

281. GERVAIS, supra note 25 , at 217-18. 
by the TRIPS Agreement since December $1998 .{ }^{282}$ Among the most controversial issues for the TRIPS Council were the discussions about the review of Article 27.3(b). ${ }^{283}$ The Doha Ministerial Declaration ${ }^{284}$ addressed the review of Article 27.3(b) by broadening the discussion. ${ }^{285}$ The issues raised in the discussions included how to apply the existing TRIPS provisions on patenting biotechnological inventions, how to define the meaning of effective "sui generis" 286 protection for new plant varieties, how to deal with the traditional knowledge, folklore and genetic material, the rights of the communities where these originate, and how to implement the TRIPS Agreement and the CBD together. ${ }^{287}$

Addressing these issues, many arguments were raised. ${ }^{288}$ First, arguments concerning protection for plant varieties and animal inventions were raised. ${ }^{289}$ Proponents for protection by patents argued that adequate protection at an international level was necessary to promote investment and facilitate transfer of technology. ${ }^{290}$ However, counter-arguments urged that the broad patent protection would facilitate bio-piracy. ${ }^{291}$ Second, different views about the scope of the exceptions to patentability were raised: ${ }^{292}$ whether a part of the

282. See id. at 227.

283. Id. at 227.

284. Id .

Four issues on the agenda of the Doha Ministerial Conference were the negotiations on geographical indications (both the negotiations for a multilateral system for notifying and registering geographical indications and the issues of expansion of the scope of additional protection); a separate declaration on TRIPS and health; work on clarifying the relationship between the TRIPS Agreement and CBD; and a number of implementation issues, including non violation complaints and the obligations in respect of technology transfer. Id. at 43 .

285. TRIPS: Reviews, Article 27.3(B), supra note 279. In Doha Ministerial Declaration, Article 71.1 was also addressed with Article 27.3(b). GERVAIS, supra note 25, at 217. Article 71.1 concerns review and amendment of the TRIPS Agreement by WTO Council. Id. at 368 . Article 71.1 states that the WTO Council for TRIPS shall review the implementation of this Agreement after the expiration of the transitional period referred to in paragraph 2 of Article 65 . ld. at 368-69. The Council shall, having regard to the experience gained in its implementation, review it two years after that date, and at identical intervals thereafter. Id. at 369. The Council may also undertake reviews in light of any relevant new developments which might warrant modification or amendment of this Agreement. Id.

286. TRIPS: Review, Article $27.3(B)$, supra note 279. The sui generis system of rights is an alternative, unique form of intellectual property protection, designed to fit a particular context and needs. Geoff Tansey, Trade, Intellectual Property, Food and Biodiversity; Key issues and options for the 1999 review of Article 27.3(b) of the TRIPS Agreement, available at http://quno.org/geneva/pdf/economic/Discussion/Trade-IP-Food-Biodiversity-English.pdf (last modifed May 24, 2005)

287. TRIPS: Reviews, Article 27.3(B), supra note 279.

288. See GeRVAIS, supra note 25 , at 228-30.

289. Id. at 228 .

290. Id.

291. Id.

292. Id. 
plant or animals is patentable; whether microorganism should be excluded from patentability, and whether classification in Article 27.3(b) should correspond to classification in the CBD. ${ }^{293}$ Third, arguments about sui generis protection of the plant varieties and elements of effective sui generis protection were addressed. ${ }^{294}$ While proponents of sui generis protection argued that protection of plant varieties is beneficial for agricultural development, others believed that such protection is disadvantageous for agriculture or traditional communities and knowledge of less-developed countries. ${ }^{295}$ Also, the issue of elements of effective sui generis protection, such as subject-matter of a sui generis right, duration of the right, or procedural requirements was addressed. ${ }^{296}$ Fourth, arguments concerning traditional knowledge were raised. ${ }^{297}$ Less-developed countries alleged that the protection of plant varieties, especially plants with medicinal characteristics, has an effect on the protection of traditional knowledge. ${ }^{298}$ These countries believed that the current Article 27.3(b) is flexible enough to protect the traditional knowledge and indigenous communities. However, developed countries expressed the view that the sui generis system in TRIPS primarily targeted the protection of the commercial varieties of plants, and TRIPS did not prevent members from protecting farmers' rights within their national sui generis system of protection. ${ }^{299}$

\section{Relationship between $C B D$ and TRIPS}

The discussions raised under the TRIPS Council have dealt with the relationship with the CBD, as well as the review of Article $27.3(\mathrm{~b}) .{ }^{300}$ However, depending on the countries, the positions on these issues differ. ${ }^{301}$ Some countries argue that there is inherent conflict between TRIPS and the CBD and, therefore, TRIPS should be amended to remove such conflict. ${ }^{302}$ Many less-developed countries have held this position. ${ }^{303}$ Proponents of this view argue that patentability of genetic material under TRIPS leads to appropriation of the natural sources and materials by private parties and that it is inconsistent with the sovereign rights of countries supported by the CBD. ${ }^{304}$

293. Id.

294. Id. at 229.

295. Id.

296. Id.

297. Id.

298. Id.

299. Id. In addition to these four issues, the issues such as ethical exceptions to patentability, relation to Union for Protection of New Varieties of Plants (UPOV), and transfer of technology were raised. Id. at 228-30.

300. Id.

301. See STAFFler, supra note 2, at 23.

302. GeRVAIS, supra note 25 , at 230-31.

303. See STAFFLR, supra note 2 , at 23.

304. GERVAIS, supra note 25, at 231. The main obligations of CBD are: 1) recognition of the sovereign rights of States over their biological resources; 2) access to biological resources 
They also argue that TRIPS does not require prior informed consent and benefit-sharing, as provided for in CBD. ${ }^{305}$ Proponents of this view suggest amendments to exclude patentability of life forms or inventions based on traditional or indigenous knowledge from TRIPS. ${ }^{306}$

On the contrary, the other countries argue that TRIPS does not conflict with the $\mathrm{CBD} .^{307}$ In general, developed countries, including the United States, follow this view. ${ }^{308}$ Proponents of this view argue that the objectives and purposes of TRIPS and the CBD are different, and granting patent rights over genetic material does not conflict with provisions of the CBD regarding the sovereign rights of countries over their genetic material. ${ }^{309}$

Nonetheless, less-developed countries argue that they feel consistently exploited because of structural imbalance between countries rich in biological diversity and those strong in technological and legal instruments. ${ }^{310}$ They contend the CBD is intended to conserve and use biological diversity of lessdeveloped countries on a long-term basis, while TRIPS is intended to provide private property rights over products and processes. ${ }^{311}$ According to the lessdeveloped countries' standpoint, the TRIPS Agreement influences the provisions of the pre-existing CBD in the access to genetic resources, the fair and equitable sharing of benefits from the utilization of genetic resources, and the respect for traditional knowledge held by the indigenous communities. ${ }^{312}$

First, less-developed countries argue that CBD Article 15.1 recognizes the sovereign rights of States over their national resources and that national governments might determine access to genetic resources. ${ }^{313}$ Also, under CBD Articles 14.4 and 14.5, the CBD simply submits access to genetic resources to the "prior informed consent" of the party on mutually agreed terms aimed at sharing the benefits arising from the utilization of such resources. ${ }^{314}$ However, on the contrary, it is said that biological resources should be subject to private intellectual property rights under TRIPS Articles 21 and $27 .{ }^{315}$ Thus, lessdeveloped countries assert that the conflict arises, while national sovereignty in the CBD implies that countries have the right to prohibit patents on life forms, and TRIPS requires provisions of intellectual property rights on life forms. ${ }^{316}$

can only occur with the prior and informed consent of States, and 3) protection and promotion by the signatories of the rights of communities, farmers, and indigenous peoples vis-à-vis their biological resources and traditional knowledge systems. STAFFLER, supra note 2, at 28-29.

305. GERVAIS, supra note 25 , at 231.

306. Id.

307. Id.

308. See STAFFLER, supra note 2, at 23.

309. GERVAIS, supra note 25, at 231.

310. STAFFLR, supra note 2, at 29.

311. Id.

312. See id.

313. Id. at 30.

314. Id.

315. Id.

316. Id. at 29. 
Second, according to CBD Articles 15.7 and 19.2, the use or exploitation of biological resources must give rise to equitably shared benefits. ${ }^{317}$ However, under TRIPS Article 27.1, patents must be provided for all fields of technology, and intellectual property rights must protect the use or exploitation of biological resources. $^{318}$ There is no mechanism for sharing benefits between a patent holder in one country and the donor of material in another country from which the invention is derived. ${ }^{319}$ Thus, less-developed countries argue for this issue because while CBD gives developing countries a legal basis to demand a share of benefits, TRIPS does not mention that legal authority for benefit-sharing. ${ }^{320}$

Third, CBD Articles 18.4 and $8(j)$ state that the use or exploitation of traditional knowledge, innovations, and practices relevant to the use of biodiversity must give rise to equitably shared benefits. ${ }^{321}$ However, as with the use or exploitation of biological resources, there is no mechanism to share benefits with the less-developed country from whose traditional knowledge the invention is derived in TRIPS. ${ }^{322}$ For this issue, less-developed countries also argue that TRIPS does not have any legal system to guarantee benefit-sharing for their traditional knowledge or their natural resources. ${ }^{323}$

\section{E. Proposals to Settle the Dispute}

As previously stated, the main concerns in the relationship between TRIPS and CBD are patenting the genetic material and protection of the traditional knowledge. ${ }^{324}$ As presented in illustrations in Part III, there have been disputes about patenting the genetic material as well as patents using traditional knowledge between developed countries and less-developed countries. $^{325}$ After the issues were raised, the discussion in the TRIPS Council went into considerable detail with a number of proposals offered to settle the disputes between developed countries and less-developed countries. ${ }^{326}$ Several countries including the United States, India, and Thailand submitted the proposals. $^{327}$

The European Union proposed to examine "a requirement that patent applicants disclose the origin of genetic material as a subject in itself, with legal consequences outside the scope of patent law."328 Switzerland proposed to

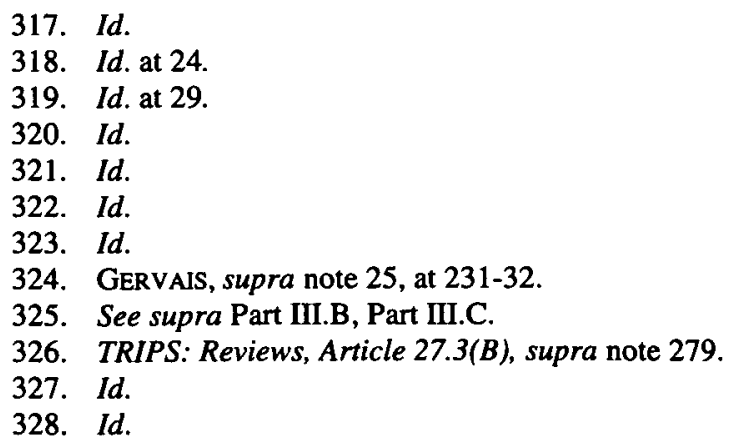


amend WIPO's Patent Cooperation Treaty $(\mathrm{PCT})^{329}$ so that domestic laws may ask inventors to disclose the origins of genetic resources and traditional knowledge for patent application. ${ }^{330}$ The African Group wants TRIPS to prohibit patenting of all life forms, including plants, animals, and microorganisms. ${ }^{331}$ This Group also wants sui generis protection for plant varieties to preserve farmers' rights to use and share harvested seeds. ${ }^{332}$

The other group of less-developed countries, ${ }^{333}$ including India and Thailand, submitted a proposal to amend TRIPS so that patent applicants are required to disclose the origins of the biological resources and traditional knowledge used in the inventions, evidence that they received prior informed consent, and evidence of fair and equitable benefit sharing. ${ }^{334}$ The proposal of this group reflects the provisions of $\mathrm{CBD} .^{335}$ In contrast, the United States argued that CBD's objectives on access to resources and traditional knowledge and on benefit sharing could be achieved through national legislation and contractual arrangements based on the legislation that included commitments on disclosure. $^{336}$

\section{CONCLUSION}

Today, as biotechnology develops, patent law to protect patent rights of life forms also has been expanded. ${ }^{337}$ Since biotechnology is a high-risk and research-intensive activity requiring large amounts of investment, the importance of patent rights is emphasized. ${ }^{338}$

Currently, the United States, one of the most technologically developed countries in the world, has been particularly concerned both with biotechnology applications and products and with patent law. ${ }^{339}$ Having jumped on the biotechnology boom, the United States turned its attention to an unconventional form of resources: living materials or traditional knowledge found in less-

329. Id. International Patent Cooperation Union established PCT. Id. PCT, signed in 1970 and later amended, makes it possible to seek patent protection simultaneously in each of a large number of countries by filing an international patent application. RYAN, supra note 36, at 96. The international patent application through PCT contains the name of the application, the title of the invention, a description including an abstract, the claims for patent, and the member states or region in which a patent is sought. Id. The application through PCT is the same as if the application had been independently filed in the state's patent office. Id.

330. TRIPS: Reviews, Article 27.3(B), supra note 279.

331. Id.

332. Id.

333. Id. The other countries in this group were Bolivia, Brazil, Cuba, Ecuador, Peru, and Venezuela. Id.

334. Id.

335. See id.

336. Id.

337. See supra Part I.

338. See DUTFILED, supra note 3, at 152-53.

339. See supra Part I. 
developed countries. ${ }^{340}$ However, since the United States started to develop the natural resources of less-developed countries, there have been debates about whether this activity by the United States is bio-prospecting or bio-piracy. ${ }^{341}$

The United States has broadened the range of patentability of life forms since the decision in Diamond v. Chakrabarty. ${ }^{342}$ In Chakrabarty, the Court held that the micro-organism can be patented by permitting the patenting of "anything under the sun that is made by man." 343 After this decision was made, the subsequent decisions for life forms confirmed the holding of Charkrabarty. ${ }^{344}$

Disputes arose between the United States and less-developed countries since the United States developed the natural resources of less-developed countries and patented the products by its broad range of patentability. ${ }^{345}$ As presented in the case studies of the neem tree and rosy periwinkle, the United States invented or produced biotechnological products or medicine using the natural resources and traditional knowledge of less-developed countries. ${ }^{346}$

Although the indigenous people of less-developed countries possessed their resources and the traditional knowledge to use those resources for over a thousand years, they were deprived of their rights over those materials and that knowledge because of a lack of a well-organized legal system. ${ }^{347}$ After the United States developed the resources from less-developed countries, the indigenous people could not access their own natural resources because of the high costs created by the U.S. company. ${ }^{348}$ In another case, the indigenous people did not receive any compensation from the U.S. company, even though their traditional knowledge provided the main clues for the invention patented by the company. ${ }^{349}$

In the case of genetically developed crops, usually rice of less-developed countries, the situation is worse. ${ }^{350}$ As shown in the case studies of basmati rice and jasmine rice, rice is the nutritional mainstay in less-developed countries and the main source of their incomes. ${ }^{351}$ Although these countries developed and conserved many varieties of rice, they did not have patent rights in those varieties due to their weak patent law systems. ${ }^{352}$ After the companies of the United States acquired samples of rice and genetically engineered those samples to make close substitutes, the rice export markets of less-developed

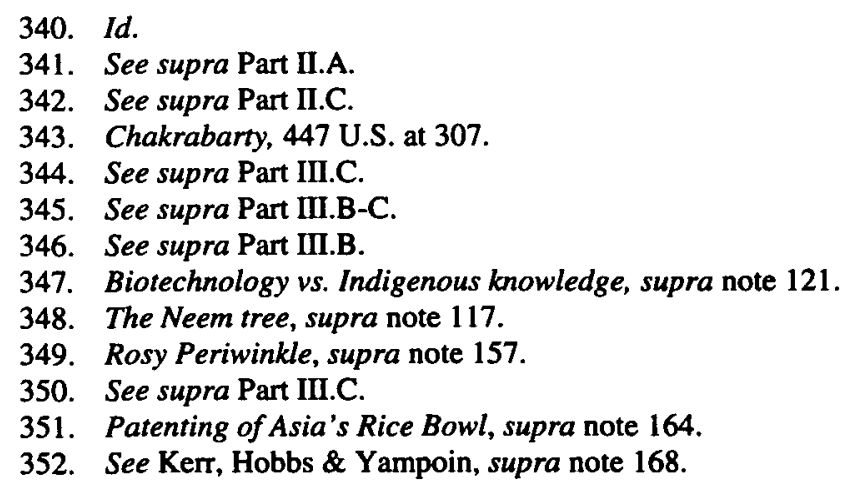


countries were threatened. ${ }^{353}$ A U.S. company even trademarked the traditional name of rice, "Basmati," and sold its rice under this name. ${ }^{354}$ Consequently, less-developed countries lost not only their rights over their rice and know-how, but also their reputation for rice. ${ }^{355}$ Often, this controversy over rice creates negative feelings among farmers and citizens of less-developed countries toward the United States. ${ }^{356}$

Then, is the development activity of the United States in less-developed countries bio-prospecting or bio-piracy? If developed countries and lessdeveloped countries have different positions for the development of natural resources, what would be the best solution to this dispute? After the conflict between developed and less-developed countries over patents regarding traditional knowledge and natural resources was raised, efforts to resolve the conflict under an international treaty, such as TRIPS, have been on-going. ${ }^{357}$

TRIPS is known as the most comprehensive, multinational treaty dealing with the protection of intellectual property rights. ${ }^{358}$ However, although TRIPS sets out standards of intellectual property protection for signatory nations to follow, issues such as the relationship between TRIPS and the CBD and the clarification of TRIPS Article 27.3 are still under review. ${ }^{359}$ The parties are trying to find mutual agreements between developed countries and lessdeveloped countries through this review process. ${ }^{360}$ Although several countries have submitted proposals to resolve the disputes, the parties have not found a compromise. $^{361}$ Each country still holds to its own position. ${ }^{362}$ A number of less-developed countries, including an African group, India, and Pakistan, proposed that TRIPS Article 27.3 be revised to exclude life forms from patenting or that countries should have full discretion to exclude any life form from patenting. ${ }^{363}$ Offering an opposing view, the European Union and the United States seek to preserve the status quo of the existing TRIPS text. ${ }^{364}$ They propose to preserve the present textual ambiguities of TRIPS that may be exploited in the implementation process, and they want to work through bilateral treaties on stronger intellectual property standards than TRIPS. ${ }^{365}$

Therefore, to resolve the disputes between the developed countries and less-developed countries, each side should step back. The United States, the most powerful country in the world, has a social responsibility to protect the

353. See supra Part III.C.

354. Basmati Rice Update, supra note 174.

355. See supra Part III.C.

356. See supra note 205 and accompanying text.

357. See supra Part IV.A.

358. Long, supra note 206, at 249-50.

359. See supra Part IV.B-C.

360. See supra Part IV.

361. Id.

362. Id.

363. See supra Part IV.E.

364. Id.

365. Id. 
interests of countries unable to protect themselves. It should not deliberately interpret the TRIPS Agreement in a manner restrictive to less-developed countries. If it insists on its position without compromising with other countries, its development activities may be regarded as bio-piracy rather than bio-prospecting, and such activities may generate strong negative feelings from less-developed countries. On the other hand, less-developed countries should attempt to accelerate domestic industrialization and implement well-organized patent laws instead of resisting the agreements under the international treaty; only a well-organized national patent law system will protect them from this fast developing world. 
